\title{
The Jewish Community Library in Vienna: From Dispersion and Destruction to Partial Restoration
}

Richard Hacken

hacken@byu.edu

Follow this and additional works at: https://scholarsarchive.byu.edu/facpub

Part of the European Languages and Societies Commons, Jewish Studies Commons, and the Library and Information Science Commons

\section{Original Publication Citation}

Richard Hacken. "The Jewish Community Library in Vienna: From Dispersion and Destruction to Partial Restoration." Leo Baeck Institute Year Book 47 (2002): 151-172.

\section{BYU ScholarsArchive Citation}

Hacken, Richard, "The Jewish Community Library in Vienna: From Dispersion and Destruction to Partial Restoration" (2002). Faculty Publications. 1335.

https://scholarsarchive.byu.edu/facpub/1335 accepted for inclusion in Faculty Publications by an authorized administrator of BYU ScholarsArchive. For more information, please contact ellen_amatangelo@byu.edu. 


\title{
The Fewish Community Library in Vienna: From Dispersion and Destruction to Partial Restoration*
}

\author{
BY RICHARD HACKEN
}

On 25 October 2000, Austria's first memorial to Jewish victims of the Holocaust was unveiled at the Judenplatz in Vienna. Conceived by Nazi hunter Simon Wiesenthal and designed by British sculptress Rachel Whiteread in the form of a nameless library, a concrete block displays shelves of books with their spines turned to the inside, enclosing an area made inaccessible by a permanently locked door. The outer memorial is designed to represent Jewish culture and learning that were lost forever in the Holocaust, while the empty space within symbolises the many readers of the library who did not live on. ${ }^{1}$ Parallel to the readers and authors of Jewish books systematically destroyed in the concentration camps, many of the books themselves were also annihilated.

If any historic collection had served as a model for the nameless library at the Judenplatz, the most likely one would have been the library of the Israelitische Kultusgemeinde Wien (Jewish religious community of Vienna, hereafter IKG). As with the insights symbolically entombed in an inaccessible library, the amalgam of spiritual and worldly wisdom that was once stored on the IKG library's shelves is now impossible to reconstruct. No one can compile a complete bibliography of its looted, scattered and decimated volumes. A look at the history of its developing collections, however, can indicate just how great an intellectual treasure went to ruin in the organised lootings orchestrated during the Third Reich and in other unforeseen events.

A limited number of documents remain behind, bearing witness to the grandeur of the collection, the circumstances surrounding its sudden disappearance from Vienna, the presumed fate of scattered segments, and the library's partial restoration.

\footnotetext{
*I wish to thank Martinus Nijhoff International book dealers and the Creative Projects Committee of the Brigham Young University Library for travel support that led to documentation for this article. Various individuals connected with the Jewish community in Vienna were particularly helpful, including librarians Irma Wulz, Mirjam Triendl and Sabine Frank along with the former library director, Dr. Ronald Grosz and the current director, Werner Hanak. Equally gracious and accommodating were Dr. Murray Hall and Dr. Kurt Schubert of the University of Vienna, Mag. Hana Keller of the Austrian State Archives, Dr. Herbert Exenberger and Dr. Siegwald Ganglmair of the Documentation Archive of the Austrian Resistance, and the Viennese historian Dr. Evelyn Adunka. Mr. Efroyim Grossberger, independent researcher on the Committee for the Search of the Góra Kalwaria Library, pointed me to vital sources at a crucial point in the research.

${ }^{1}$ Sue Masterman, 'Remembering: Austria Opens First Holocaust Memorial', online at ABCNews.com, (http://abcnews.go.com/sections/world/DailyNews/memorial.html).
} 


\section{FORMATION AND BEGINNINGS}

Nothing could be more natural for the People of the Book than to prize the written word. Still, publicly accessible Jewish libraries in the modern sense were slow to develop in European metropolitan centers - especially when compared to the rich and vast holdings within educational institutions, private libraries, and rabbinical seminaries. The Jewish community of Vienna is reported to have been one of the first, after the communities of Amsterdam and Mantua, to create a library for the general use of its members. ${ }^{2}$

In April 1814 the gentile printer Anton Schmid presented one copy of each of the Hebrew works he had published, 133 volumes in all, to the Jewish community of Vienna. The most recent printing at that time had been a twelve-volume edition of the Talmud. Accompanying the gift was a German-language dedication printed in the Hebrew alphabet that expressed gratitude for "generous support from the revered Israelite nation". ${ }^{3}$ This accompanying document itself received the call number "l" in the subsequent library catalogue. ${ }^{4}$ The collection of gift volumes, which Schmid was later to augment with donations of further publications, became the nucleus around which the Jewish community library was built.

The gift book collection, in accordance with the wishes of the benefactor, was housed in the temple at the building complex known as Dempfingerhof..$^{5}$ This complex, comprising the area now designated as Seitenstettengasse 4 and Fleischmarkt la in central Vienna, had been acquired by the IKG in 1814 - the same year as the acquisition of Schmid's gift books - for the purpose of building a major synagogue. Indeed, it seems that the completion of the main synagogue at this site in 1826 under the architectural guidance of Josef Kornhäusel marked a high point in Viennese Jewish life. ${ }^{6}$

As a public institution, the library had some maturing to do: at first it seems to have been more of a showcase than a lending library. By the year 1850, though, Leopold Breuer, the Hebrew teacher, had arranged for a modest annual operating budget from the community leadership and had expanded usage of the collection into a school and community library. At the same time that the IKG leadership

\footnotetext{
${ }^{2}$ Alexander Kristianpoller, 'Die Bibliothek der Wiener Kultusgemeinde. Ihre Entstehung und Entwicklung', in Menorah: Züdische Familienblätter für Wissenschaft, Kunst und Literatur, vol. IV, No. 3 (March 1926), pp. 194-195. Kristianpoller was the librarian of the second largest Jewish library in Vienna, the library of the Israelitisch-Theologische Lehranstalt ("Jewish Theological Seminary"). See also footnote 26.

${ }^{3}$ As quoted by Gustav Kohn and Moriz Leinkauf, Bericht der II. Section (Unterrichtswesen) über die Entstehung und Entwicklung der Bibliothek der israel. Cultusgemeinde in Wien, Vienna 1896, p. 3. Anton Schmid had become one of Austria's most successful publishers and a nobleman. The title following his name at the bottom of the dedication reads: "k.k. privil. u. niederösterr. Landschafts-Buchdrucker" ("Regional Book Printer for Lower Austria by Royal and Imperial Appointment"). By long-standing statute, no Jewish printer in Vienna had been allowed the privilege - or appointment - to print the Hebrew books necessary for worship and education.

${ }^{4}$ Kohn and Leinkauf, p. 2.

${ }^{5}$ Kristianpoller, p. 195. Dempfingerhof, a distortion of Pempflingerhof, was named after the earliest known owner of the property.

${ }^{6}$ See entry for "Pempflingerhof' in Felix Czeike, Historisches Lexikon Wien, Vienna 1992-1997, vol. IV, p. 513.
} 
approved an annual subsidy of 60 Gulden for the library, it also followed the suggestion of Ludwig August Frankl ${ }^{7}$ to make a request for book acquisitions to the chief of police, Baron von Kempen. The request was sent with the following wording: "Might those Hebraic works and those relating to Judaism in German which are sent to the high office as mandatory deposits, and which are not used for official purposes, be donated to the library of the local [Jewish] Religionsschule."8 The decision to grant the request came only six days later, and a number of volumes were acquired in this manner. ${ }^{9}$ Looking back from the vantage point of the twenty-first century, it seems a manifest irony that some of the books later to be destroyed or confiscated and systematically screened for value by agents of the Gestapo had first been acquired through the generosity of the local police.

Even after receiving a number of municipal gifts, the library's volume count had only reached 514 (as compared with thirty to forty thousand by 1938). These works were housed in an annexe to the Hebrew Religionsschule in the Seitenstettengasse. ${ }^{10}$ This annexe was actually a small cabinet with three walls, a space so inadequate that the books had to be stacked two deep. There was no question of a reading room, so the library functioned only as a lending facility. ${ }^{11}$

\section{GROWTH AND ENRICHMENT}

Significant expansion took place only after Samuel Hammerschlag, newly hired in 1857 as a teacher in the Religionsschule, took on the administration of the library as one of his duties. It was early in his tenure that Hammerschlag insisted the library reach out to become a public institution. Both the collection growth and the rising demand for reading hours called for appropriate increases in space through the years. Reports of the Education Section of the IKG (under which the library was subsumed) trace a steady progression. In 1880-1881 an adjoining room was allocated to the bulging library. Thanks in large part to efforts of the renowned scholar Salomo Gottlieb Stern, the dual catalogue, in Hebrew and German, was fully compiled by 1887. The school moved out of its former quarters in the spring of 1893, leaving more space for expansion of the library that was to include a reading room with five windows. Gaslight gave way to electricity two years later. ${ }^{12}$ The weekly number of hours for the reading room increased from 6.5 to 11 hours in 1893 and again from 11 to 24 hours in $1903 .^{13}$

\footnotetext{
${ }^{7}$ Secretary of the Viennese Jewish community from 1838 until after the 1848 revolution, by 1850 Ludwig August Frankl had already established himself in the public consciousness as a poet. In 1848 his poem 'Die Universität' had circulated as the first uncensored leaflet in Austria.

${ }^{8}$ As quoted by Kohn and Leinkauf, p. 4 .

${ }^{9}$ ibid., p. 5. These were often defective or individual volumes of cabbalistic or talmudic-halakhic series printed in Hungary and Galicia.

${ }^{10}$ Ronald Grosz, ‘Die Bibliothek des Jüdischen Museums Wien', in Werner Hanak, ed., Papier ist doch weiss? Eine Spurensuche im Archiv des Füdischen Museums Wien, Vienna 1998, p. 167.

${ }^{11}$ Kohn and Leinkauf, p. 6.

${ }^{12}$ ibid., pp. 10-12. See also Kristianpoller, pp. 197-199.

${ }^{13}$ Bericht des Vorstandes der Israelitischen Kultusgemeinde in Wien über seine Tätigkeit in den Fahren 1902 und 1903. Vienna 1904, p. 11.
} 
Hammerschlag's acquisitive acumen was to continue throughout this entire period as well - nearly half a century, from 1857 until 1903. In May of 1873 he was forced to retire from his teaching post due to the onset of deafness. For the final three decades of his life, without pay but also without any time-consuming distractions, he worked at developing the library. Since he had few funds his collecting policy consisted of purchasing only the most essential of newly printed books, waiting until other titles became available on the antiquarian market. Staying in direct contact with the major antiquarian dealers of Germany, he was able to make significant purchases at advantageous rates. This was particularly true for works in Hebrew. Materials acquired in this manner included rare and valuable specimens, incunabula and first editions. ${ }^{14}$ Though the first area of collection building was in Jewish literature, broadly understood, other subjects found representation: religious history in general, patristic literature to the extent it served as a source for Jewish - as well as non-Jewish - religious thought, Christian theological treatises to the extent they dealt with Jewish literature, polemics against Judaism, and so forth. ${ }^{15}$

A second prong of the collection strategy was to canvass vigorously for book donations from the erudite - and in some instances famous - local members of the Jewish community. As a result, the next few decades saw significant growth through gifts of private collections, of which only a few examples will be cited. ${ }^{16}$ After the death of Leopold Breuer, the teacher mentioned earlier as a catalyst of the library's funding, relevant portions of his private collection, including valuable titles no longer available on the antiquarian market, were transferred to the IKG library by agreement with his son, Dr. Josef Breuer. ${ }^{17}$ After the death of Hermann Löwy, a number of his Hebraic works were presented to the library by his son-in-law, Dr. Leopold Kompert. At the death of Dr. Kompert, the latter's widow donated many of his books to the library, complementing the writer's earlier donation of his collected works. ${ }^{18}$ Dr. Ludwig August Frankl was another of the dozens of major donors to the library. ${ }^{19}$ One of the greatest benefactors in the latter part of the nineteenth century was the president of the Israelitische Kultusgemeinde, Dr. Ignaz Kuranda, who presided over subsidies to the library that reached 500 Gulden by 1883. Before his death, Kuranda had offered his private collection, asking Hammerschlag to pick out titles of value to the library, including a great array of Hebrew works, and these were acquired after his passing.

The most famous and undoubtedly most valuable gift of books to the Viennese Jewish community library was a twofold donation by Salo Cohn. In 1896 he acquired the collection of the renowned bibliographer and collector S. J. Halberstamm in Bielitz for the price of 6,000 Gulden - which at the time amount-

\footnotetext{
${ }^{14}$ Kohn and Leinkauf, p. 9.

${ }^{15}$ ibid., p. 6.

${ }^{16}$ ibid., pp. 7-8; Kristianpoller, pp. 197-199.

${ }^{17}$ Josef Breuer was a well-known psychological theorist and clinician in his own right. He would later be the co-author, with Sigmund Freud, of Studien über Hysterie.

${ }^{18}$ Kompert had published a series of tales entitled Aus dem Ghetto in 1848, and had attained some fame as a journalist and writer. He was also president of the education section for the IKG and an education advisor at the ministerial level in Lower Austria.

${ }^{19}$ See footnote 7 .
} 
ed to twelve years of the annual library budget - and presented it to the community library. This general collection contained twenty-eight incunabula from the years 1476-1492, amounting to one-third of all known Hebrew incunabula. ${ }^{20}$ Twenty of these were first editions. The Halberstamm collection encompassed 421 works of various sorts, bound in 390 volumes, most of which possessed great rarity value. Among them were 176 works from the sixteenth century encompassing fifty-eight first editions, with each decade of that century represented, plus the first book of any sort printed in the Middle East. Twenty-four books had manuscript supplements, and the editio princeps of the Jerusalem Talmud had an entire manuscript appended. ${ }^{21}$

The second part of the donation came over a decade later when Cohn purchased the greater part of Rabbi Nahum Beer Friedmann's library. This contained recent and rare hasidic writings that were not present even in such libraries as the Bodleiana in Oxford because of their unique nature: they were largely non-trade books of individual pious hasids that had been given to Rabbi Friedmann. ${ }^{22}$

The historian who succeeded Samuel Hammerschlag as head of the library, Dr. Bernhard Wachstein, compiled a descriptive catalogue of both Salo Cohn gift collections. ${ }^{23}$ At the time of Hammerschlag's death in 1904, the collection had expanded to well over 10,000 volumes and had outgrown its surroundings. In 1906 the library was moved en masse to the Jewish community building at Ferdinandstraße 23 in Vienna's second district, Leopoldstadt. ${ }^{24}$ The library was no longer considered an annexe to the religious school, but rather an independent institution in its own right. ${ }^{25}$

A qualitatively impressive local acquisition was made in 1926 with the transfer of the manuscript collection of the Israelitisch-Theologische Lehranstalt to the library. A trio of scholars in Eastern Europe and Vienna had painstakingly collected this parchment and paper manuscript collection for its scholarly value. ${ }^{26}$ Simultaneously, the book collection had branched out by the mid-1920s to encompass such topics as the Kabbalah, ghetto literature, and the so-called Jewish Renaissance, including litera-

${ }^{20}$ Bericht des Vorstandes der Israelitischen Kultusgemeinde in Wien über seine Tätigkeit in den Fahren 1910 und 1911, Vienna 1912, p. 19.

${ }^{21}$ Kohn and Leinkauf, pp. 12f. The further comment is made (p. 14) that bibliographic rarity was only one aspect of the collection; another was its intrinsic value for talmudic studies.

${ }^{22}$ Bericht des Vorstandes der Israelitischen Kultusgemeinde in Wien über seine Tätigkeit in den Fahren 1908 und 1909, Vienna 1910, pp. 19-20. As noted by Bernhard Wachstein (see footnote 23), Rabbi Friedmann, considered a "miracle rabbi," had been a direct descendant on his mother's side of Rabbi Beer, the original rabbi to systematise Hasidism.

${ }^{23}$ Bernhard Wachstein, Katalog der Salo Cohn'schen Schenkungen, 2 vols., Vienna 1911.

${ }^{24}$ Bericht des Vorstandes der Israelitischen Kultusgemeinde in Wien über seine Tätigkeit in den Fahren 1906 und 1907, Vienna 1908, p. 25. By 1936, according to the Bericht des Präsidiums und des Vorstandes der Israelitischen Kultusgemeinde Wien über die Tätigkeit in den Fahren 1933-36, Vienna 1936, p. 102, the library would expand to cover two floors in the synagogue complex at Tempelgasse 5, the IKG archives being transferred to Ferdinandstraße 23.

${ }^{25}$ Kristianpoller, p. 199.

${ }^{26}$ Bericht der Israelitischen Kultusgemeinde Wien über die Tätigkeit in der Periode 1925-1928, Vienna 1928, p. 30. The transfer may have had something to do with the desperate financial straits of the Lehranstalt's library: see Zum vierzigjährigen Bestehen der Israelitisch-Theologischen Lehranstalt in Wien, Vienna 1933, p. 164: "The story of our library is a sad one now as ever; there have been as good as no acquisitions for it since the [First World] War". 


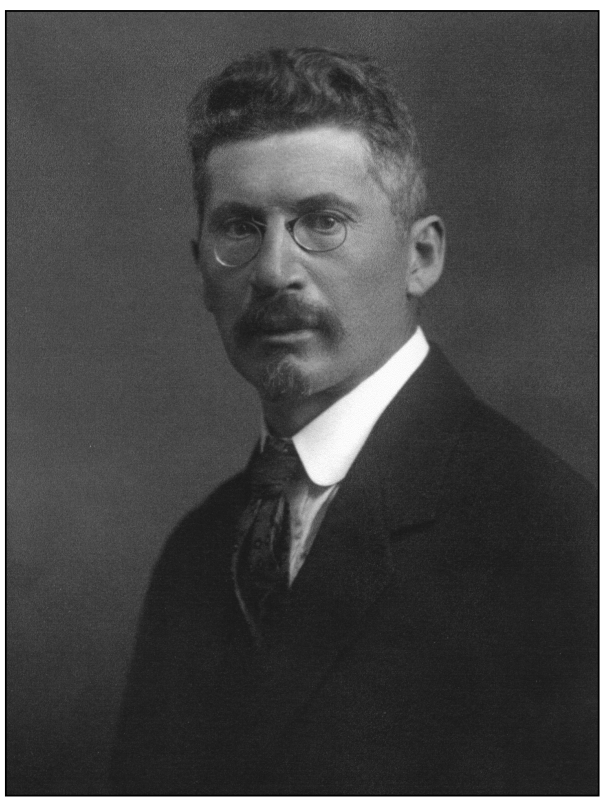

Dr. Bernhard Wachstein.

ture of Judaism on the intellectual side and Zionism and Palestine studies on the practical side. ${ }^{27}$

Wachstein provided significant scholarly impetus to the library and, until his death in 1935, was to preside over its veritable Golden Age..$^{28}$ One measure of the prestige increasingly attending the library was the volume of requests for book loans to scholars in various international locations. While library reports from the years 1906 through 1936 regularly mention "active interlibrary loan with institutions in this country and abroad", 29 the report for 1929-1932 in particular mentions manuscript materials being used by a Professor Davidson in New York, a Professor Blondheim by way of the Bibliothèque nationale in Paris, Dr. Michael Wilensky at the Preußische Staatsbibliothek, and others. The same report tells of many University of Vienna students using the IKG holdings for completion of dissertations in literary history and art history. ${ }^{30}$ Public

\footnotetext{
${ }^{27}$ Ernst Müller, 'Die jüdische Gemeindebibliothek in Wien', in Füdisches Leben in Österreich in Wort und Bild, mit Gemeinde- und Vereinskalender für das Jahr 5686 (1925-1926), Vienna 1926, pp. 36-37.

${ }^{28}$ Grosz, p. 167. The memoirs of Dr. Wachstein's daughter, Sonia Wachstein, Hagenberggasse 49. Erinnerungen an eine Wiener jüdische Kindheit und Jugend, Vienna 1996, offer a glimpse into his personal and family life.

${ }^{29}$ Bericht des Präsidiums und des Vorstandes der Israelitischen Kultusgemeinde Wien über die Tätigkeit in den Jahren 1933-36, Vienna 1936, p. 100. The years of the First World War were an exception for international lending, of course, but the Bericht der Israelitischen Kultusgemeinde Wien über die Tätigkeit in der Periode 1912-1924, Vienna 1924, pp. 25-26, reports that the period saw a great increase in local usage.

${ }^{30}$ Bericht der Israelitischen Kultusgemeinde Wien über die Tätigkeit in der Periode 1929-1932, Vienna 1932, p. 36. The biannual report for 1900-1901, p. 13, had already commented on university professors making use of the collection.
} 
relations and outreach programmes for the Jewish community library stand out in the documentary history. Shortly before the First World War, the library had taken part in the International Fair for Book Trade and Graphics at Leipzig, where it received a certificate of honour. ${ }^{31}$ In 1925 the Fourteenth Zionist Congress met in Vienna, and the library took this occasion to exhibit its rare Hebrew incunabula. ${ }^{32}$

The intent of the Jewish community library in Vienna seems to have been the same as its reputation: to be, in the words of Saul Chajes, not only a central point for Jewish intellectual life in Vienna but a centre of Jewish scholarship in general. ${ }^{33}$ The number of volumes in 1938 has been very conservatively estimated at 33,800hundreds of them rare books and thousands of them monetarily and intellectually valuable - with 41 incunabula and 645 manuscripts, 300 of which were extremely valuable. ${ }^{34}$ Such was the stature of the library at the time of Austria's absorption into the Third Reich. By then, the library had become one of the largest and most significant Jewish community collections in Europe and was on a par with the libraries of Berlin, Prague, Frankfurt and Breslau. ${ }^{35}$

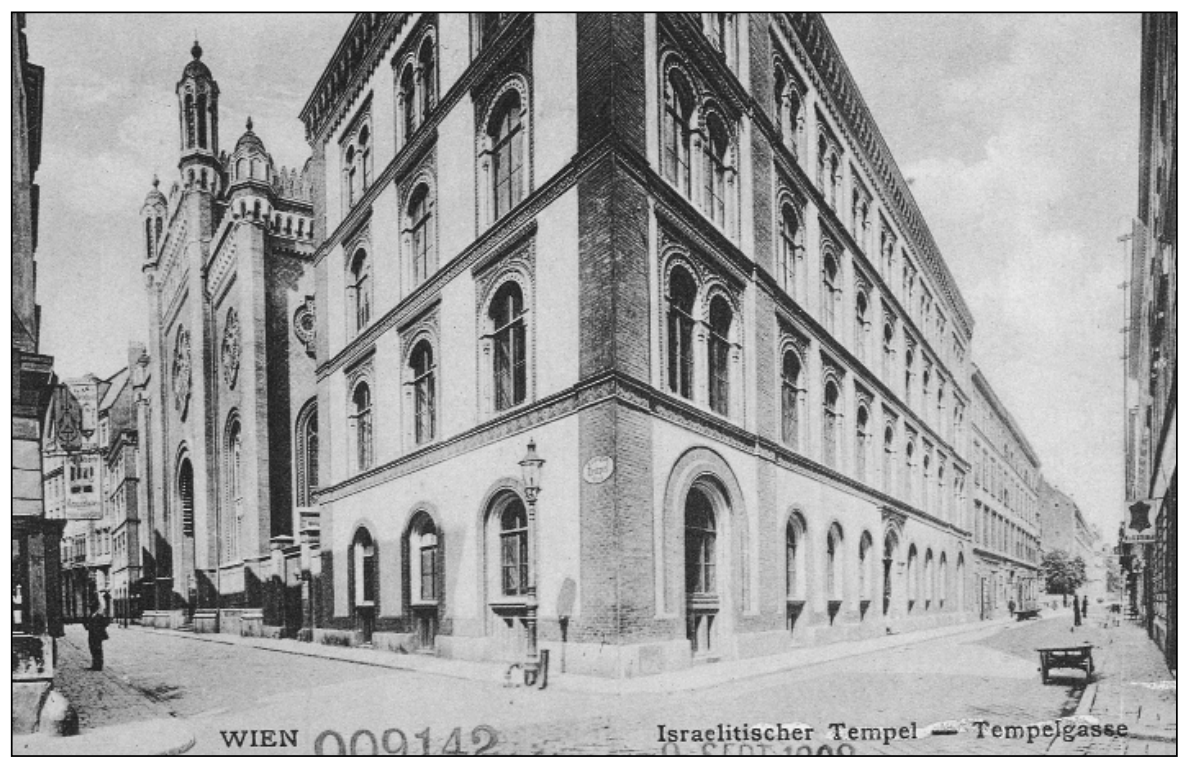

Synagogue, Tempelgasse 5, Vienna, before 1938.

By courtesy of Jüdisches Museum, Wien

${ }^{31}$ Bericht der Israelitischen Kultusgemeinde Wien über die Tätigkeit in der Periode 1912-1924, Vienna 1924, p. 26.

${ }^{32}$ Bericht der Israelitischen Kultusgemeinde Wien über die Tätigkeit in der Periode 1925-1928, Vienna 1928, p. 30.

${ }^{33}$ Saul Chajes, 'Die Sammlungen der jüdischen Gemeinde in Wien', in Füdisches Fahrbuch für Österreich, Vienna 5693 (1932), p. 116.

${ }^{34}$ Commission on European Jewish Cultural Reconstruction, 'Tentative List of Jewish Cultural Treasures in Axis-Occupied Countries', in Jewish Social Studies, vol. VIII, No. 1, supplement (1946), pp. 27f. The volume count can be adjusted upward, perhaps as high as 40,000, since the report takes acquisition indices into account only through 1929.

${ }^{35}$ Schulamith Schmidt, 'Jüdische Bibliotheken in der Zeit des Nationalsozialismus', in Peter Vodosek and Manfred Komorowski (eds.), Bibliotheken während des Nationalsozialismus, Wiesbaden 1992, vol. I, p. 510. 
At the time of Bernhard Wachstein's death in January 1935, the National Socialist Party had already taken power in Germany. Yet even before the Anschlu $\beta$, Jewish life had been different in Austria: over ninety per cent of Austrian Jews lived in a single metropolis, Vienna. With over 176,000 individuals in 1934, the Jewish community represented over nine percent of the city's population and over fifty per cent of its lawyers, physicians and dentists. ${ }^{36}$ The Viennese Jewish community was thus the largest in German-speaking Europe and the third largest in Europe after Warsaw and Budapest. ${ }^{37}$ Despite the threatening actions of the National Socialist government in Germany, before March 1938 the Austrian Jews hardly revealed a mood of widespread apprehension. On the one hand, the Jewish community regarded the Dollfuß-Schuschnigg government as its protector, despite the exclusion of Jews from public service and despite other spiteful regulations. The Austrian government, in the view of many community members, had put down a Nazi uprising in 1934, had put an end to antisemitic violence, and had made the streets safe again for those of the Hebrew faith. There was a false sense of security in assuming that Austria had already rejected Hitler. ${ }^{38}$ On the other hand, Jewish society was so splintered and at times acrimonious - there were liberals and nationalists, the secular and orthodox, modernists and traditionalists, Western and Eastern Jews, assimilationists and Zionists - that most of its members were hardly in a position to fully detect the rise of Nazism around them. ${ }^{39}$

The partisan acrimony extended to the library itself. A newly convened Zionist leadership in the Viennese Jewish community appointed one of its own, Moses Rath, to head the library in April 1935 after Dr. Wachstein's death. Rath was not a librarian nor did he have the benefit of relevant training. This procedural coup called forth great opposition within the community, especially since numerous Austrian and foreign scholars - among them noted personalities like Saul Chajes - had indicated great interest in the position even before Dr. Wachstein's death. Dr. Leopold Moses, the IKG archivist, was assigned to be Rath's assistant. ${ }^{40}$

From that time until the closing of the library by the National Socialists in July 1938, no further scholarly publications were forthcoming from the IKG. This included Leopold Moses' own dissertation on the history of rural Jewish communities in

\footnotetext{
${ }^{36}$ Evan Burr Bukey, Hitler's Austria: Popular Sentiment in the Nazi Era, 1938-1945, Chapel Hill, NC-London 2000, p. 131, and Herbert Rosenkranz, 'The Anschluss and the Tragedy of Austrian Jewry 1938-1945', in Josef Fraenkel (ed.), The Jews of Austria: Essays on their Life, History and Destruction, London 1967, p. 480.

${ }^{37}$ Evelyn Adunka, 'Die Wiener jüdische Gemeinde und der Antisemitismus nach 1945', in Martha Keil and Eleonore Lappin (eds.), Studien zur Geschichte der Juden in Österreich, Bodenheim 1997, p. 205.

${ }^{38}$ Harriet P. Freidenreich, Fewish Politics in Vienna, 1918-1938, Bloomington, IN 1991, pp. 202f, notes: "While some might blame Austrian Jewry for unwisely putting all their eggs in a single basket [Schuschnigg], by that time no other receptacles were available." See also Bruce F. Pauley, From Prejudice to Persecution: A History of Austrian Anti-Semitism, Chapel Hill, NC-London 1992, pp. 277-279: 'Jewish Optimism in the Last Days of Austrian Independence'.

${ }^{39}$ Bukey, pp. 132-133: symptomatically, there were 444 Jewish organizations in Vienna before the Anschlu $\beta$, of which only 88 were religious or prayer groups.

${ }^{40}$ Die Wahrheit, 17 April 1935, p. 3.
} 
Lower Austria, today considered a standard work on the topic, which had to be published in a different publishing house. ${ }^{41}$ Rath was relieved of his office after the Anschlu $\beta$, and Nazi officials designated Dr. Moses provisional director of both the archive and library.

Following the Berchtesgaden Conference of 12 February 1938 between Hitler and Austrian Chancellor Schuschnigg, at which point annexation seemed imminent, the main security office in Berlin responsible for ideological research and evaluation, Amt II of the Sicherheitsdienst $(\mathrm{SD})^{42}$ prepared its Austria campaign. This was to include the confiscation of files, books and archival materials as well as other forms of battle against intellectual and ideological opponents. The Anschlu $\beta$ of Austria presented Heinrich Himmler, head of the SS, and Reinhard Heydrich, ${ }^{43}$ director of the SD, with a first major test case for the participation of security police and SD in imminent annexation operations in the Sudetenland, Czechoslovakia, Poland, neighbouring Western European countries, and finally the Soviet Union. ${ }^{44}$ It is thus not surprising to find that these and other top Nazi officials were directing operations in Vienna during the spring of 1938.

Even before troops crossed the border, Adolf Eichmann was deeply involved in the pre-planning to defeat potential Viennese opponents in the context of the SD Amt II112 assignment he held prior to directing technical details of the Holocaust at SD Amt IV-B-4. This has been documented in his own words:

Several weeks before the Anschlu $\beta$ we had worked up the Austria campaign on catalogue cards. [...]We located the Jewish functionaries and Freemasons in all areas of Weltanschaung [from SD and Gestapo files]. We sat at our benches like schoolboys and wrote out the catalogue cards; then they were organised and arranged alphabetically while matters that weren't so imminent were pushed aside. With this array of catalogue cards in hand, the first wave of the SD "rushed" down to Austria. ${ }^{45}$

A certain irony has to be seen in the Nazis' use of catalogue cards to index their ideological enemies, since this was a category that would soon extend to the books of the Jewish community library. Commandos of SD Amt II subsequently searched rooms and storage areas of various "opposing groups" in March and April 1938, during which certain files and books "of importance to the Reich" were shipped to Berlin and others were pulped. ${ }^{46}$

Franz Alfred Six, head of SD Amt II at the time, had dispatched the "Zionism expert" Eichmann from Berlin to Vienna "to personally take over the central lead-

\footnotetext{
${ }^{41}$ See Patricia Steines, biographical essay introducing Leopold Moses' memoirs, Spaziergänge, Vienna 1994, p. 10; Leopold Moses, Die jüdischen Landgemeinden in Niederösterreich mit besonderer Berücksichtigung des 17. Fahrhunderts, Vienna 1935.

${ }^{42}$ Amt II, entitled Gegnerforschung ("Enemy Research"), was later to be renumbered Amt VII upon the integration of the Sicherheitsdienst into the Reichssicherheitshauptamt (hereafter RSHA). Amt VII, under the leadership of Franz Six and later Paul Dittel, came to be called Weltanschauliche Forschung und Auswertung ("Ideological Research and Evaluation").

${ }^{43}$ Heydrich, assassinated in Czechoslovakia in 1942, was later replaced as director of the Sicherheitsdienst by Himmler himself and then by the Austrian Ernst Kaltenbrunner.

${ }^{44}$ Lutz Hachmeister, Der Gegnerforscher. Die Karriere des SS-Führers Franz Alfred Six, Munich 1998, p. 192.

${ }^{45}$ Adolf Eichmann, Ich, Adolf Eichmann, ed. by Rudolf Aschenauer, Leoni am Starnberger See 1980, p. 85.

${ }^{46}$ Hachmeister, p. 192f.
} 
ership of the Austrian Jewish question on location". ${ }^{47}$ On 18 March, two days after his arrival, Eichmann took matters personally in hand by participating in a raid on the IKG in the Seitenstettengasse, during the course of which documents linking the Jewish community to financial support of Schuschnigg's plebiscite campaign were confiscated. ${ }^{48}$ His control over the situation regarding books was just as intense. According to at least one source - Rabbi H.J. Zimmels - Eichmann's personal interest in the value of the IKG collection expressed itself strongly in the form of a threat: the librarian, Dr. Moses, would be held personally responsible for any missing book. Unfortunately one of the books, Richard Beer-Hofmann's Jakobs Traum, had been in the possession of a student arrested by the authorities shortly before. The rabbi personally canvassed remaining bookstores to find a copy of the missing book; according to Rabbi Zimmel's notes from the summer of 1938, he finally succeeded in locating a copy and delivering it to the library. ${ }^{49}$

The Gestapo had informed the director of the IKG installed after the Nazi takeover, Dr. Josef Löwenherz, that a decree of 9 April 1938 placed the Jews of Austria under the same legal and logistical strictures as those within the Altreichsgebiet. ${ }^{50}$ Eichmann's first official gesture towards Dr. Löwenherz, on 2 May 1938, was to slap his face. ${ }^{51}$ From that time onward Löwenherz was subjected to ever-increasing pressures by the SD authorities, most of which involved Jewish emigration and the confiscation of real estate and other possessions from those forcibly exiled. Then, according to postwar courtroom testimony given by Wilhelm Bienenfeld, Assistant Director to Dr. Löwenherz and a later member of the Fudenrat, the Israelitische Kultusgemeinde lost ownership rights to both its library and archive on 19 July 1938, when Dr. Löwenherz was forced to sign them away:

On the 19th of July 1938, U!Stuf. [= Untersturmfiihrer] Eichmann forced a Declaration of Relinquishment regarding the library and archives of the Israelite Jewish community of Vienna, which, according to the statement of U!Stuf. Eichmann, were to be taken to Berlin in their entirety, stored there, and used only for purposes of scholarly research. $\mathrm{He}$ imposed the most stringent vow of silence on Dr. Löwenherz, basing this on the possibility that incorrect rumours could leak out [“unrichtige Gerüchte nach aussen dringen könnten”] because of the transfer. ${ }^{52}$

\footnotetext{
${ }^{47}$ Bundesarchiv Koblenz, R 58/613, as quoted by Hachmeister, p. 195. Eichmann oversaw the creation of the Zentralstelle fü jüdische Auswanderung, a means of forcing Jewish emigration from Austria.

${ }^{48}$ Hans Safrian, Die Eichmann-Männer, Wien-Zurich 1993, p. 37.

${ }^{49}$ As quoted by Peter M. Manasse, Verschleppte Archive und Bibliotheken. Die Tätigkeiten des Einsatzstabes Rosenberg während des Zweiten Weltkrieges, St. Ingbert 1997, p. 106.

${ }^{50}$ Österreichisches Staatsarchiv, Archiv der Republik (hereafter OeStA/AdR), 04 Büro Schmidt, fol. 919. Dr. Löwenherz acknowledged receipt of this letter with his signature.

${ }^{51}$ Bukey, p. $134 f$.

${ }^{52}$ Dokumentationsarchiv des Österreichischen Widerstandes (subsequently DÖW), document folder 8919a, excerpt of a transcript from the trial of the Austrian Volksgericht against SS-Sturmbannfïrer Dr. Karl Ebner on 28 December 1945. While Steines, p. 13, gives the date as 19 June 1938, both Manasse, p. 106, and Hugo Gold, Geschichte der Fuden in Wien, Tel Aviv 1966, p. 78, give it as 19 July 1938. Herbert Rosenkranz, Verfolgung und Selbstbehauptung. Die Fuden in Österreich 1938-1945, Vienna 1978, pp. 152f., claims that the transfer did not take place, but this statement is based on an alleged eyewitness, the provisional leader of the Jewish community before Dr. Löwenherz, Dr. Isidor Klaber, who was most likely not in a position to be aware of the highly secretive SD transfer nearly eight months after the declaration.
} 
On closer examination, this preemptive confiscation of the Jewish community library by the SD reflects a move to stave off competing agencies within the Third Reich. The property of Jews emigrating as individuals or as families, including personal libraries or even bookstores and publishing houses in private ownership, became the spoils of the Reich through what was termed "Aryanisation". A regulation lending the appearance of legitimacy to this practice would not be enacted until 25 November $1941 . .^{53}$ The Reich Treasury thus took upon itself the power to distribute any seized private property, often to its own enrichment but also to the advantage of agencies other than those within the RSHA. Jewish community property such as that of the IKG, on the other hand, presented a special case. The Reich Treasury could not lay claim to such property because the Israelitische Kultusgemeinde, as a composite legal entity, was incapable of emigrating. Since the Jewish community came under the control of the RSHA, the reality was that SD and Gestapo officers confiscated and decided on the disposal of such communal library collections. ${ }^{54}$

The SD and Gestapo did not shrink from "securing" property even before the exile or deportation of individuals, and police officers dealing with the contents of Jewish apartments were directed to deliver the private book collections to the RSHA. A directive to all divisions from Munich dated 24 April 1939, numbered 84/39 and signed by Martin Bormann on behalf of the Reich Minister of the Interior, Wilhelm Frick, was designed to unify the initial sorting of book and archival holdings under the aegis of the Gestapo. It addressed the perceived problem of confiscated library materials being scattered throughout various agencies:

For uniform inspection and evaluation, it is requisite for the seized materials to be collected first at the offices of the Secret State Police. I therefore order that all archival and written holdings seized on the occasion of the Fudenaktionen ["aus Anlass der Fudenaktionen"] be delivered immediately, unaltered and completely, to the local State Police office or branch office. ${ }^{55}$

Most of the book confiscation campaigns in Vienna took place before this directive and well before the official establishment of the RSHA on 27 September 1939. ${ }^{56}$ Hence, the segmented nature of literature in the Third Reich - as intellectual property, economic niche, cultural phenomenon, perceived philosophical threat and intended propaganda tool - set numerous agencies of the National Socialist regime against one another like so many jackals fighting over prey. One potential competitor was the chief Nazi theoretician, Alfred Rosenberg, who had a long-abiding interest in assembling Judaica and Hebraica for the pseudo-science of his projected Institut zur Enforschung der Fudenfrage ("Institute for Research into the Jewish Question") at a special university for ideology and racial research (the term devised for this was Hohe Schule). ${ }^{57}$

\footnotetext{
${ }^{53}$ As an 11 th Ordinance to the Reich Citizenship Law: Reichsgesetzblatt, 1941, p. 722.

${ }^{54}$ Dov Schidorsky, 'Confiscation of Libraries and Assignments to Forced Labor: Two Documents of the Holocaust', in Libraries and Culture, vol. XXXIII, No. 4 (Fall 1998), pp. 348-349.

${ }^{55} \mathrm{OeStA} / \mathrm{AdR} / 04$, Stillhaltekommissar Anordnungen (Verfügungen betr. Sicherung der Vermögenswerte). The final statement of the directive states that each piece was to be carefully indexed. ${ }^{56}$ Israel Gutman (ed.), Encyclopedia of the Holocaust, New York 1990, p. 782.

${ }^{57} \mathrm{OeStA} / \mathrm{AdR} / 04$ Bürckel-Materie, fol. 2445/2, letter of Alfred Rosenberg to Gauleiter Bürckel of 6 March 1939: "[T] he preparation of a good library for the projected Hohe Schule is one of the most crucial tasks I have to set myself (eine der vordringlichsten Aufgabe [sic], die ich mir stellen muss)".
} 
Rosenberg did have at least one ally in Vienna. Der Beauftragte fir die kulturellen Fragen in Österreich ("The Commissioner for Cultural Questions in Austria"), Professor Alois Haasbauer, sent a letter to the local Gau leadership on 7 June 1938 in which he claimed control of literary policy matters in the Gau for his office. This was a duty to run simultaneously with assistance for Reichsleiter Rosenberg in matters of literary surveillance. ${ }^{58}$

Einsatzstab Reichsleiter Rosenberg für die besetzten Gebiete ("Reich Leader Rosenberg's Special Unit for the Occupied Areas"), with its stated aim of "securing the cultural possessions of Jews, Freemasons, Jewish organisations and lodges and transporting them to Germany," ${ }^{59}$ did not technically include Austria in its purview and was not established until 17 July $1940 .{ }^{60}$ Rosenberg's unit later became a direct competitor to the various branches of the RSHA and to Josef Goebbels' Reichsministerium fuir Volksaufklärung und Propaganda (hereafter RMVP) ("Reich Ministry for Popular Enlightenment and Propaganda"). ${ }^{61}$ In Vienna, though, elements of the nascent RSHA had got to the library holdings of the IKG ahead of Rosenberg. ${ }^{62}$

The Propaganda Ministry had set up a Bücherverwertungsstelle ("book-evaluation location") at Dorotheergasse 12 in Vienna for the evaluation and distribution of confiscated titles from bookstores, publishing houses and private libraries. This was in apparent cooperation with the Gestapo and the SD, however, and was not designed to include titles from the Jewish community library. ${ }^{63}$

\footnotetext{
${ }^{58} \mathrm{OeStA} / \mathrm{AdR} / 04$ Korrespondenz Diverses, Haasbauer, fol. 114. An example of Haasbauer's influence is found in his letter of 14 June 1938 to the library administration of the University of Vienna, instructing them to increase their holdings of National Socialist "standard works" such as Mein Kampf and Mythos and to avoid "Catholic-tinged" works. (OeStA/AdR/04 Bürckel Materie, fol. 2421).

${ }^{59}$ Bundesarchiv Koblenz R6/170, p. 8 ("Regelung des Einsatzes des Sonderkommandos Reichsleiter Rosenberg"), as quoted by Dov Schidorsky, 'Das Schicksal jüdischer Bibliotheken im Dritten Reich', in Peter Vodosek and Manfred Komorowski (eds.), Bibliotheken während des Nationalsozialismus, Wiesbaden 1992, vol. II, p. 202.

${ }^{60}$ Bundesarchiv Koblenz NS 8/132, P. 54, as quoted by Schidorsky, 'Das Schicksal jüdischer Bibliotheken im Dritten Reich', p. 201

${ }^{61}$ Schidorsky, 'Das Schicksal jüdischer Bibliotheken im Dritten Reich', pp. 192, 207, passim. For Rosenberg's book-collecting power struggle with a Viennese office of the RMVP, see footnote 64. Also see Jan-Pieter Barbian, Literaturpolitik im “Dritten Reich," Frankfurt am Main 1993, pp. 390-391. Donald E. Collins and Herbert P. Rothfeder, 'The Einsatzstab Reichsleiter Rosenberg and the Looting of Jewish and Masonic Libraries during World War II', in fournal of Library History, vol. XVIII, No. 1 (Winter 1983), p. 34, conclude that "Jewish and Masonic literature profited from the work of Alfred Rosenberg. [...]. [His] pseudo-scholarly endeavours helped to preserve the cultural and literary treasures of Jewish and Masonic Europeans for posterity."

${ }^{62}$ Thus, the claim by Philip Friedman, Roads to Extinction: Essays on the Holocaust, New York-Philadelphia 1980, p. 93, that "[a]mong the confiscated collections incorporated in Rosenberg's Frankfurt Institute were the libraries of the[...]Jewish community and the rabbinical seminary in Vienna" seems to be unfounded, though individual titles with the IKG book stamp may have found their way there.

${ }^{63}$ For details on this book evaluation centre, see Otto Seifert, 'Bücherverwertungsstelle Wien I, Dorotheergasse 12', in Jahrbuch Dokumentationsarchiv des österreichischen Widerstandes, 1998, pp. 88-94. The article is documented with sources from the archive of the Deutsche Bücherei in Leipzig, the home institution of the imported expert, Albert Paust, who had begun operating the book evaluation centre in the autumn of 1938. See also Maria Kühn-Ludewig, 'Bücherverwertungsstelle Wien 1938-1939', in Displaced Books. Bücherrückgabe aus zweierlei Sicht, Hannover 1999, pp. 18-20. Through 25 May 1939, according to a report by Paust, 644,000 volumes had been collected and sorted in the book evaluation centre, of which around two-thirds $(410,000)$ were pulped. Of the other titles, Paust's own Deutsche Bücherei in Leipzig was a major recipient, as was the Nationalbibliothek in Vienna, but also the Preußische Staatsbibliothek in Berlin and the Bayerische Staatsbibliothek in Munich.
} 
The Propaganda Ministry included a Reichskulturkammer ("Reich Chamber of Culture") ${ }^{64}$ with a Division VIII in charge of Schrifttum ("Literature"). The Vienna office of a subdivision within the latter division, the Parteiamtliche Prüfungskommission zum Schutze des NS-Schriftums (hereafter PPK) ("Official [Nazi Party] Testing Commission for the Protection of National Socialist Literature"), went far beyond the bounds of its assigned censorship, into the realm of book confiscation. ${ }^{65}$

On 2 November 1938, one week before the November pogrom, Dr. Lothar Kühne, leader of the Viennese branch of the PPK, sent a packet of materials to the offices of Reichskommissar Josef Bürckel. ${ }^{66}$ The first item in the packet was a letter defending the PPK's area of jurisdiction as a branch of the Schriftum Division of the RMVP. To complicate the lines of authority just a bit, it was also Dr. Kühne who had organised the book centre in the Dorotheergasse two months before and had thus come to some accommodation with the Gestapo and SD. He made a special point of claiming that "regarding jurisdiction for confiscation, there should be no doubt that that is exclusively a matter for the Reichsleitung of the NSDAP", thus calling upon the Reichskommissar to ratify his authority. The second part of the packet contained a memorandum about the value of material slated for confiscation, principally titles yet to be seized from bookstores and publishing houses. Then followed a further justification for the PPK's role in confiscation. A third document in Kühne's packet to the Reichskommissar was a draft of orders, unsigned and dated only with month and year (that is, "Wien, den ... Oktober 1938"), perhaps intended for Bürckel to sign. The orders consisted of three parts: (1) the NSDAP was to seize "all remaining literature in the Ostmark detrimental to the National Socialist Weltanschaunng"; (2) the Vienna office of the PPK, with Party Member Dr. Lothar Kühne named specifically, was commissioned and empowered to carry this out; and (3) mention was made of an earlier order of 22 June "regarding the securing of materials historically important to the party for documenting the struggle between the movement and its opponents in Austria".

It is clear that Dr. Kühne was in communication with the SD and Gestapo but equally clear that his assignment did not extend beyond private libraries, bookstores and publishing houses. The local zeal of the PPK had been effectively trumped by the orders of Heydrich in November, before the looting, when the latter commanded: "The archives of the Jewish communities are to be confiscated by the police, so that they will not be destroyed [in the planned anti-Jewish riots]. Important in this

\footnotetext{
${ }^{64}$ By 1937 Goebbels had also created a semi-autonomous Sonderreferat Reichskulturwalter Hinkel zur Überwachung der geistig und kulturell tätigen fuden im deutschen Reichsgebiet ("Reich Cultural Supervisor Hinkel's Special Division for the Surveillance of Intellectually and Culturally Active Jews within the German Reich").

${ }^{65} \mathrm{OeStA} / \mathrm{AdR} / 04$ Bürckel-Materie, fol. 2445/2 documents interagency power struggles through complaints directed against the PPK and its local director, Lothar Kühne. One of the most interesting of these involves a letter of 6 March 1939 to Viennese Gauleiter Bürckel by Alfred Rosenberg in which the latter claims that "the PPK has, at Gau level, absolutely no right to confiscate scholarly materials or even entire libraries."

${ }^{66} \mathrm{OeStA} / \mathrm{AdR} / 04$ Bürckel-Materie, fol. 2445/2. Bürckel's full title was Reichskommissar für die Wiedervereinigung Österreichs mit dem Deutschen Reich ("Reich Commissioner for the Reunification of Austria with the German Reich").
} 
respect is the historically valuable material." 67 The principle applied to libraries as well as archives. Thus it remained for the SD in Vienna to carry out orders to secure ideologically and historically important writings by taking physical command of the Jewish community library. This occurred during the pogrom unfolding in the night of 9 to 10 November 1938 ("Kristallnacht"). The next day, on 10 November, Wilhelm Nußmüller, an assistant in the Vienna office of the Kriminalpolizei, filed a report with Gestapo regional headquarters:

Secret State Police

State Police Regional Headquarters, Vienna

Vienna, 10.11. 1938

\section{$\underline{\text { Report }}$}

In the course of the fudenaktion on 10.11.38 at around 6:00 a.m., accompanied by three other persons, I secured the Jewish library housed in the structure of the Jewish temple, Vienna II, Tempelgasse 5. The rooms were placed under lock and seal. The synagogue and surrounding rooms had already been destroyed by the enraged populace, so it was no longer possible to secure any valuables that might possibly have been located in the temple itself.

In accordance with the directive issued [laut der ergangenen Weisung], SS-Ustf. Schröder of the SD Upper Section in Vienna was informed of the action. After previous consultation with SS-Ustf. Mandl of the SD Subsection in Vienna, the keys were given to SS-Ustf. Dr. Höttel of the SD Subsection in Vienna.

Wilhelm Nußmüller, Commissioned Criminal Police Asst. ${ }^{68}$

Locking up the library was clearly a prearranged and orchestrated action, as evidenced by the phrase "in accordance with the directive issued".

It did not take long for potential recipients of the library to place their acquisition requests before the officials of the Sicherheitsdienst. An internal SD memo of 16 November, less than a week after Kristallnacht, shows that such a request had been made the previous day for receivership of the library in toto:

On the occasion of book confiscations by the SD Subsection from various temples and prayer houses, along with the accompanying dwellings, at which the undersigned was himself present, the perception was formed that book requests were being made by various National Socialist institutions. Among others, the Archivist of the City of Vienna, Dr. Till of the Municipal Archives of the community of Vienna, Tel. A 28-5-00, ext. 253, requested the library of the Isr. Kultusgemeinde located in the Tempelgasse. He based this request on the observation that this library, as well as books located in the private possession of Jews and in that temple and its side rooms, possess an uncommonly great value for the State Archive. Dr. Till was informed by me that such a confiscation

\footnotetext{
${ }^{67}$ Nuremberg document PS-3051 in International Military Tribunal, Nuremberg 1947-1949, vol. XXXI, pp. 515-519, as quoted by Friedman, p. 98. In Vienna, the library and the archives were stored and processed separately.

${ }^{68}$ DÖW 1456.
} 
could only proceed with the cooperation of the Secret State Police. After inspection, the room where the library is located was once again officially sealed by the undersigned.69

The request of the archivist was apparently turned down in keeping with Eichmann's earlier statement that the library was to be transported to Berlin in its entirety. A less ambitious and more successful request was made around the same time, though. SS-Führer Kern of the Amt für Sippenforschung (Bureau for Genealogical Research), located in the offices of the Reichskommissar, also visited the IKG collections to inspect register books of great importance for the tracing of family lines. These were sealed in two coffers to be delivered to the IKG offices in the Seitenstettengasse on 16 November, the same date as the memo. ${ }^{70}$

Insofar as the documentation shows, after these predatory visits the library remained in a state of guarded limbo for over three months. ${ }^{71}$ During this time Leopold Moses was the sole person to be permitted entry, for specific purposes and only at the express permission of Adolf Eichmann. ${ }^{72}$

On 24 February 1939, Dr. Moses was given a direct commission from Eichmann to "prepare an inventory list of Vienna's Kultusgemeinde library within eight days". ${ }^{73}$ The next day, even before the inventory lists had been prepared, Eichmann communicated with Berlin about the Jewish library. The evidence for this is the rough draft of a communiqué from Berlin dated 7 March 1939 and addressed to the head of the SD in Vienna:

To the SD-Führer of the Danube SS-Upper Section, II 112, Vienna

Regarding: Recently seized Jewish library in Vienna.

Event: Oral Communication from SS-H'Stuf. [= Hauptsturmfuihrer $]$ Eichmann of 25.2.39.

SS-H'Stuf. Eichmann communicated to us here on 25.2. that [just this year] an extensive Jewish library [has been secured]. Since the rooms in which it is located had been designated for use as a Jewish rest home, a determination about its further use needs to be made as soon as possible.

[Since] use of the library cannot be [decided upon] without a knowledge of its contents, [we request the employment of a librarian]. ${ }^{74}$

It is unclear whether the message was ever sent in its final form, but the draft seems to exhibit uncertainty about, or ignorance of, Eichmann's wishes for the library to be sent to Berlin in its entirety.

\footnotetext{
${ }^{69} \mathrm{DÖW} 1456$.

${ }^{70}$ DÖW 1456. By this time, Nazi officials had occupied the offices of the IKG (Gold, p. 78). The genealogical materials were evidently used for the purposes of establishing claims regarding racial status.

${ }^{71}$ Steines, p. 13, notes that near the end of this time, on 17 February 1939, Dr. Moses, who was also the curator of the former Jewish Museum, had to receive a delegation of the Völkerkundemuseum (Ethnological Museum) for the ethnologists to "inspect" the stored holdings of the Jewish Museum - presumably for potential confiscation.

${ }^{72}$ Steines, p. 13.

${ }^{73}$ ibid.

${ }^{74}$ Eichmann. Henker, Handlanger, Hintermänner. Eine Dokumentation, Berlin 1961, p. 17. Words and phrases in square brackets represent handwritten additions or changes to words and phrases that had been crossed out.
} 
Pseudo-scholars and ideologues besides Rosenberg desired to tap the riches of Jewish scholarship for their own purposes of racial documentation and research. One of the most virulent organisations of this type was Ahnenerbe ("Ancestral Heritage"), which was administered by the SS under Amt II (later Amt VII) of the RSHA at the behest of Heinrich Himmler. ${ }^{75}$ The Zentralbibliothek der Fudenforschung of Amt VII was located in a former Freemason lodge building on Emserstraße in Berlin. It was to this centralised RSHA repository that the plundered libraries of many Jewish communities were shipped, including the Vienna holdings of the Kultusgemeinde. A postwar report of the IKG accurately notes: "A carefully arranged plan by the Nazis must have previously been in place, for the emptying of the library proceeded with true German thoroughness." ${ }^{.76}$ Other looted Jewish community libraries that were shipped to Berlin virtually intact included those of Breslau, Königsberg, Warsaw, Hamburg and Munich. Plundered private collections, such as those of André Maurois and Artur Rubinstein, also arrived at the Emserstraße library. ${ }^{77}$

A letter from Dr. Matthes Ziegler, a subordinate of Rosenberg and editor of Nationalsozialistische Monatshefte, to Dr. Alfred Bäumler, professor at the University of Berlin, dated 6 January 1939 - which is to say approximately two months before the IKG library was looted and taken away from Austria - suggests that the valuable Hebraica holdings from Vienna were viewed at that time as the basis for a Zentralinstitut fuir jüdische Forschung. No location for the institute was mentioned in the letter, however, so Ziegler could have been referring either to a Rosenberg institute that failed to materialise or to the Zentralbibliothek set up in Berlin by the RSHA the following summer. ${ }^{78}$

According to the 1946 testimony of Dr. Ernst Grumach, a Holocaust survivor who had been forced to sort books in the RSHA library of Judaism, the rooms were insufficient to house the combined total of a very conservatively estimated 200,000 to 300,000 volumes,${ }^{79}$ and so they piled up in immense heaps. There was no thought of retaining the integrity of the individual community collections. Employees of the Gestapo pulped a considerable portion of the collections after a preliminary round of sorting, but this practice was later stopped. Some parts from each collection were separated out and shelved in distinct sections. These included reference works; periodicals; Hebrew, Yiddish and Ladino literature; and an extremely valuable collection

\footnotetext{
${ }^{75}$ See Gerhard Hahn, 'Ausländische Parlamentsbibliotheken unter nationalsozialistischer Herrschaft', in Die Reichsbibliothek zu Berlin - ein Spiegel deutscher Geschichte, Düsseldorf 1997, p. 622. Ahnenerbe was also involved in the sadistic medical experiments at Auschwitz and elsewhere; see Wolfgang Benz, Hermann Graml and Hermann Weiß (eds.), Enzyklopädie des Nationalsozialismus, Stuttgart 1997, p. 353.

${ }^{76}$ Die Tätigkeit der Israelitischen Kultusgemeinde Wien in den Fahren 1952 bis 1954, Vienna 1955, p. 49.

${ }^{77}$ Schidorsky, 'Das Schicksal jüdischer Bibliotheken im Dritten Reich', pp. 193-195. This RSHA library was to move twice within Berlin, first to an even larger former Freemason lodge at Eisenacherstraße 12 and then to a synagogue in Schöneberg.

${ }^{78}$ Bundesarchiv Berlin NS 15/311 Bl. 188; see Maria Kühn-Ludewig, Johannes Pohl (1904-1960). Judaist und Bibliothekar im Dienste Rosenbergs. Eine biographische Dokumentation, Hannover 2000, p. 133: footnote 267.

${ }^{79}$ Grumach's own estimates (as cited in footnote 83 ) vary widely, since the German-language document states "2-3000 000 Bände" but his English translation states "2-300,000 volumes." Schidorsky, 'Das Schicksal jüdischer Bibliotheken im Dritten Reich', p. 194, accepts the higher figure of two to three million volumes.
} 
of Jewish and Hebrew manuscripts taken from all the confiscated libraries. ${ }^{80}$ Among the latter would have been manuscripts from Vienna acquired at the time of the Salo Cohn donations. ${ }^{81}$

The majority of the RSHA library holdings were dispersed when the various departments evacuated Berlin in August 1943 for places of relative safety in Silesia and Northern Bohemia. Most of the rearranged holdings were removed to Niemes Castle near Reichenberg (now Liberec) in Northern Bohemia, where they were organised much as they had been in Berlin. The entire Hebrew and Yiddish literature collection was sent to Theresienstadt, though, where it was processed and catalogued by resident concentration camp inmates under the direction of the Fudenältester, the Viennese scholar and rabbi Benjamin Murmelstein. ${ }^{82}$ This literature collection would have included Hebrew and Yiddish titles from the Vienna IKG, as identified by its book stamps. ${ }^{83}$

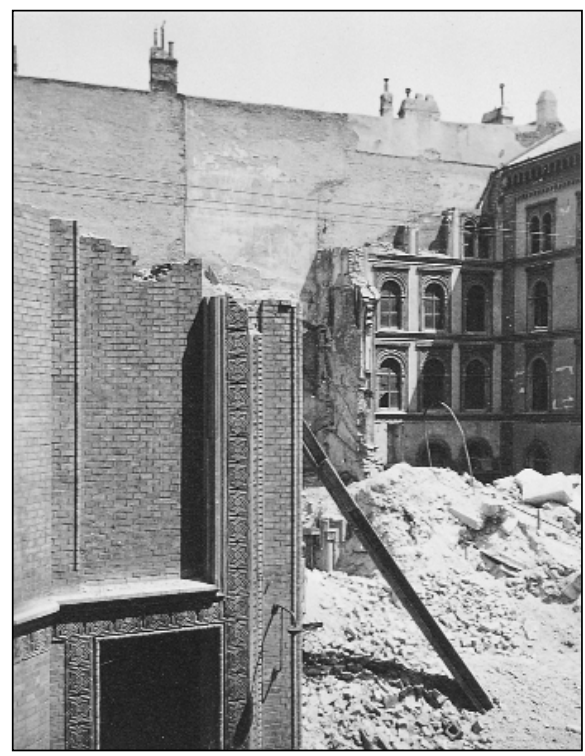

Synagogue, Tempelgasse 5, Vienna, c. 1941.

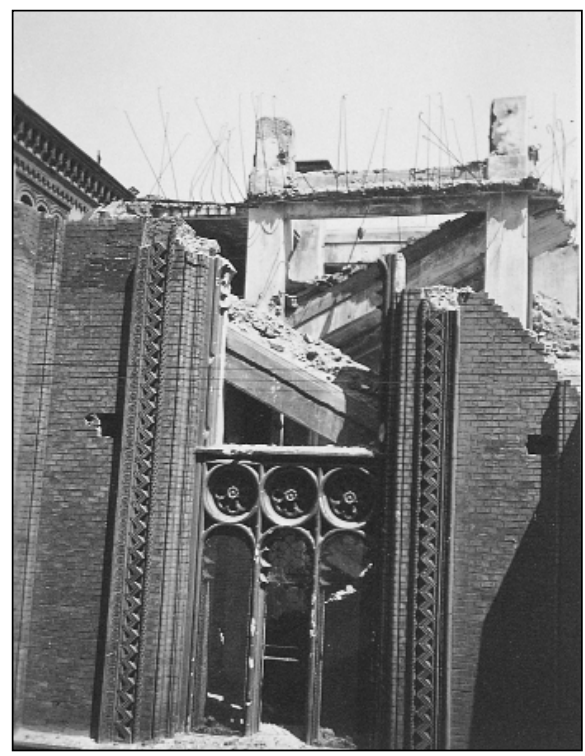

By courtesy of Jüdisches Museum, Wien

${ }^{80}$ The Central Archives for the History of the Jewish People, Jerusalem, doc. P3/2060: Ernst Grumach, 'Bericht über die Beschlagnahme und Behandlung der früheren jüdischen Bibliotheksbestände durch die Stapo-Dienststellen in den Jahren 33-45', as quoted by Dov Schidorsky, 'Confiscation of Libraries', pp. 358-359, with English translations on pp. 353-354 (contemporary translation) and 363-364 (translation submitted with the original report to the Reichsvereinigung der fuden in Deutschland).

${ }^{81}$ See footnote 23 .

${ }^{82}$ Incorrectly referred to as "Rabbi Dr. Marmorstein" by Grumach but correctly identified by Friedman, p. 97 and Schidorsky, 'Confiscation of Libraries', p. 387.

${ }^{83}$ Grumach as quoted by Schidorsky, 'Confiscation of Libraries', pp. 359-360, with English translations on pp. 355 and 364 . 
It seems beyond doubt that many of the original library holdings of the Vienna Jewish community library were left behind in Berlin, having been transferred to Eisenacherstraße 12, only to be lost forever in the autumn of 1943 :

Of the stock left in Berlin, the greater part was destroyed during the fire which broke out at the RSHA on 22 and 23 November 1943. The collections of the Warsaw and Viennese Jewish congregations' libraries were destroyed in this fire. ... Only a small part of this collection which had, by chance, been left in rooms unaffected by the fire, mainly the stocks of periodicals, was saved. ${ }^{84}$

\section{PARTIAL RESTORATION}

The library of the Israelitische Kultusgemeinde in Vienna was not totally lost without a trace when the Second World War ended. The subsequent developments have been outlined by Dr. Evelyn Adunka, a Viennese historian who has recently published a history of the IKG:

From [Vienna's] Central Cemetery the IKG was able to unearth portions of the library that had been carried off by the Nazis, and [the IKG] received back other portions from Czechoslovakia and Germany through the aid of the Labour Office, as well as the Austrian Federation of Labour Unions and Jewish Cultural Reconstruction, in the first years after the war. $^{85}$

The books that had been buried for preservation were chiefly of Hebrew content; members of the congregation had carefully wrapped and interred them in tombs or graves and in the Jewish ceremonial hall at the Central Cemetery (after the destruction of its cupola by SS troops during “Kristallnacht"). In addition, books had been secreted in various caches inside double walls of auxiliary rooms of the synagogue complex in the Seitenstettengasse, down to two cellars deep, and in walls and floors of subterranean passageways that led from the synagogue complex to surrounding buildings. ${ }^{86}$

How did a large number of wooden crates full of volumes from the former IKG Vienna library find their way to a railway station in Bohemia, to be discovered there after the war and returned to the Jewish community through the intermediary of the Gewerkschaftsbund (Federation of Labour Unions)? Only speculation is possible, but the most likely scenario posits these volumes as incomplete shipments from the RSHA library in Berlin to the less vulnerable surroundings of Niemes Castle. ${ }^{87}$

\footnotetext{
${ }^{84}$ Schidorsky, 'Confiscation of Libraries', English translation, p. 355, with German original on p. 360.

${ }^{85}$ Evelyn Adunka, Die vierte Gemeinde. Die Wiener Fuden in der Zeit von 1945 bis heute, Berlin 2000, p. 305. See also Adunka's most recent and very relevant monograph: Der Raub der Bücher. Plünderung in der NS-Zeit und Restitution nach 1945, Vienna, 2002. Die Gemeinde. Offizielles Organ der Israelitischen Kultusgemeinde Wien, No. 13 (23 January 1959), p. 3, also attributes the Austrian Federation of Labour Unions with the mediation and return of some of the books.

${ }^{86}$ Die Tätigkeit der Israelitischen Kultusgemeinde Wien in den Fahren 1952 bis 1954, p. 49; also interviews of 6 October 1999 with Dr. Ronald Grosz, then director of the IKG library and Dr. Avshalom Hodik, one of those to first catalogue the returned books.

${ }^{87}$ Die Tätigkeit der Israelitischen Kultusgemeinde Wien in den Jahren 1952 bis 1954, p. 49; also interview of 6 October 1999 with Dr. Ronald Grosz. The IKG report of the early 50s was accurate for its day in its assessment of the books returned from Bohemia: "This is the only trace pointing to the Nazis' plundering of the entire library of the Viennese religious community."
} 
These volumes were thus safely away from the makeshift library storage of Berlin's Eisenacherstraße when the fire of late 1943 broke out.

Additional books with clear provenance of the Vienna community library gradually found their way back to the IKG. In one such case, the Deutsche Gewerkschaftsbund forwarded a great number of Hebrew and German-Jewish books to the Düsseldorf congregation. Of these, the Synagogue Community of Düsseldorf identified roughly 150 volumes with the stamp of the Viennese community and, in 1955, sent them immediately back to Vienna. In harmony with sorting procedures of the RSHA in Berlin that meant shipping certain categories to Bohemia (such categories thus escaping the flames), the salvaged titles consisted of both Hebrew literature and periodicals. $^{88}$ Another return of lost IKG volumes came from Offenbach, where the American occupation forces had set up a book depot for the sorting and return of plundered books. ${ }^{89}$

On the local level, the Vienna congregation was active in identifying stolen collections that had been carried to Austria. Perhaps the most successful find was a major collection of works on dialects; it had been taken from the famous YIVO Institute (Yiddish Scientific Institute) in Vilnius. The IKG also set up a book commission in Vienna, which, with the cooperation and support of the Austrian Ministry of Education, sent a delegation to public and federal libraries to locate missing Jewish books - not only those from the IKG library ${ }^{90}$ The findings were notable: almost 200,000 volumes were located that had likely been in Jewish possession. Of these, 150,000 were restored from the library of the University of Vienna, 30,000 from the Österreichische Nationalbibliothek, and over 20,000 from a storage location in the Federal Ministry of Finance. Some 2,000 volumes - both manuscripts and printed books - had been produced in the fifteenth and sixteenth centuries and had great rarity value. The processes of identification and return were to take a considerable amount of time..$^{91}$

Some small fruits of restoration are evident in today's collection of the Jewish community library (since 1994 officially the Library of the Jewish Museum). ${ }^{92}$ The following is a tiny sample of titles surveyed at random and identified by stamps of former interim "ownership". An SS library in Vienna, the SS-Mannschaftshaus/ Bücherei Wien had taken possession of a title about Viennese Jews (Hans Tietze, Die Juden Wiens, Leipzig 1935), a Jewish lexicon (Füdisches Lexikon, Berlin 1927-1930), biographies of Moses Hess (Berlin 1921) and of the Rothschilds (Berlin, c. 1881), as well as histories of the Jews in the Middle Ages (Frankfurt a.M. 1920), under the Russian Czar (Berlin 1914) and in the First World War (Berlin 1916). The Gestapo office in Vienna had confiscated and retained numerous volumes of a recent edition of the Babylonian Talmud (Berlin 1930-). A book on the Prague ghetto (Prager

${ }^{88}$ Iskult-Presse-Nachrichten (hereafter IPN), No. $41 / 42$ (26 July 1955), p. 7.

${ }^{89}$ Die Tätigkeit der Israelitischen Kultusgemeinde Wien in den Jahren 1952 bis 1954, p. 49; for more information on the Offenbach depot, see Collins and Rothfeder, pp. 33-34.

${ }^{90} I P \mathcal{N}$, No. 13 (30 June 1954), pp. 7-9; IPN, No. 18 (30 September 1954), pp. 10-11.

${ }^{91} I P \mathcal{N}$, No. 27 (31 January 1955), pp. 8-9; see also Adunka, Die vierte Gemeinde, p. 30.

${ }^{92}$ Grosz, p. 168. The IKG placed the collections themselves on permanent loan to the Jewish Museum in 1992. 
Ghettobilder, Leipzig c. 1920) was returned from the Reichsinstitut fur Geschichte des neuen Deutschlands. The Deutsche Arbeitsfront, Amt Reichsbezugsquellen-Archiv, with its interest in historical documentation, had taken a book outlining forced exiles of Jews from Vienna (Vienna 1889). A theoretical treatise on belief and evidence by Joachim Rappaport (Vienna 1877) had found its way to the library of the Austrian parliament. One curious find was the German-language piano score for Jacques Halévy's five-act opera La Fuive (Die Füdin, Leipzig 1910), which had last been in the archives of the Vienna State Opera. Titles returned from the Offenbach Archival Depot included an anthology of poetry by German Jews, compiled by Uriel Birnbaum (Berlin 1920), and a work of historical fiction by Ernst Fürstenthal (Berlin 1936).

The above samples are small in number when compared with those now bearing earlier stamps of the University of Vienna's Orientalisches Institut, and therein lies a story. After the removal en masse of Vienna's Jewish community library to Berlin from the Tempelgasse, the library of Vienna's rabbinical seminary was moved two buildings further from its original location, to Ferdinandstraße 23, and the library holdings of the Maimonides Institute were added to it. ${ }^{93}$ In practice, this storage area became a holding area for Jewish collections that the Nazi authorities had no time to deal with. Even the holdings of some Jewish publishing houses found their way to this holding area from the PPK's Bücherverwertungsstelle and elsewhere. ${ }^{94}$

In 1943, Kurt Schubert, later to found the Institute for Judaic Studies at the University of Vienna and currently Emeritus Professor, was a young non-Jewish student. His professor, Viktor Christian, was both an antisemitic scholar of Semitic studies and a Nazi with connections to the SS pseudo-scholarly society, Ahnenerbe. A civilian member of the SS, he was also an enthusiastic collector of books having to do with Judaism. Schubert and his four fellow students of Semitics (one of whom, Franz König, was to become a cardinal in the Catholic Church) were solidly antiNazi, a fact recognised and benevolently ignored by their Nazi mentor. One of Professor Christian's bibliographic coups had been to receive books from the Munich offices of Ahnenerbe that he incorporated into the library of the Oriental Institute at the university. This library was destined to survive the war unscathed.

It was Kurt Schubert's great luck, as he puts it, that he came down with a bad case of bronchial asthma during the war, so he was not sent to fight but served as an air raid marshal in Vienna itself. His duty was to conduct air raid alarm tests and evacuation drills in the Second District, the area most populated by Jews up until 1938. In 1943, he discovered a great number of wooden crates in the basement of Ferdinandstraße 23 and on further investigation found they were crammed with books on Judaica. Since they had lain in the wet cellar for around five years, the bottom twenty percent of the books had been ruined by moisture and mould, but even the remaining eighty percent amounted to an estimated 20,000 books.

\footnotetext{
${ }^{93}$ The IKG library had been at Ferdinandstraße 23 before its expansion into the synagogue complex in the Tempelgasse: see footnote 24 and also Henry M. Metzger, 'Die Bibliothek der Wiener Kultusgemeinde', in Die Gemeinde. Offizielles Organ der Israelitischen Kulturgemeinde Wien, No. 121 (31 January 1968), p. 25.

${ }^{94}$ Grosz, p. 168, and a personal interview of the author with Dr. Kurt Schubert on 1 October 1999.
} 
When Schubert informed his professor about the books, the latter was quick to encourage his student to bring them into the library of the institute. The problem, he said, would be in convincing the Nazis in that building to give them up. In an act of necessary deception, Schubert wrote to the previous head of the local civil air defence (who now held a more prominent position), asking if the books might be released to him for destruction by burning. They might present a danger in case of an actual air attack, he pointed out, since they would only add fuel to the building. Once permission was given, he and others from the institute took the books to Berggasse 7 and added the salvageable books to the collection of the Oriental Institute.

The liberation of the city centre of Vienna took place on 9 and 10 April 1945, and Schubert turned over the contents of the wooden crates to the Jewish community the next month. Dr. Schubert reports that he was in Jerusalem on the first anniversary of the founding of the State of Israel, at which point he signed over the deed of gift for the volumes he had removed from the basement in the Second District of Vienna along with other Hebrew and Judaica books from the Orientalisches Institut that had previously been in Jewish ownership. ${ }^{95}$

\section{NEW BEGINNINGS}

The postwar library of the Jewish community of Vienna was first reassembled from the caches of hidden books mentioned earlier, from the collections taken from Ferdinandstraße 23 and placed in the Orientalisches Institut for safekeeping, and from the small percentage of original library materials that gradually returned. In practice, the IKG library also became the repository for books and other written holdings of Jewish associations, synagogues and religious communities that no longer existed. ${ }^{96}$

After 1945, the problems of displaced persons, decimated families and communities, and the despair of European Jewish life in general, overshadowed most concerns for cultural heritage. ${ }^{97}$ In the early 1950 s, emissaries from the Hebrew National and University Library travelled throughout Europe to save remnants of Jewish libraries that were, in their view, about to be lost to non-Jewish hands. Many members of the Vienna Jewish community, especially those in leadership roles, saw no future for themselves or for Judaism in Austria and were eager to show their support for Israel. Thus in 1952 and 1953, following a number of emissary visits and an intensive book exchange programme between Vienna and Jerusalem, ${ }^{98}$ the Hebrew National and University Library

\footnotetext{
${ }^{95}$ Personal interview of the author with Kurt Schubert on 1 October 1999. In an earlier interview with Konstantin Kaiser on 24 September 1986 (DÖW), Schubert related his shock that only the religious school inspector of the IKG, Isidor Oehler, had been interested in the volumes and that the books had been delivered into the building by means of a coal chute. The fact that the volumes bore the ownership stamps of the Orientalisches Institut must surely be traced back to the Ahnenerbe collecting proclivities of Dr. Christian.

${ }^{96}$ Die Tätigkeit der Israelitischen Kultusgemeinde Wien in den Fahren 1952 bis 1954, p. 49; Grosz, p. 168.

${ }^{97}$ This is reflected in the first postwar community report, Bericht des Präsidiums der Israelitischen Kultusgemeinde Wien über die Tätigkeit in den Fahren 1945 bis 1948, Vienna 1948, not containing a single paragraph about the library.

${ }^{98}$ Die Tätigkeit der Israelitischen Kultusgemeinde Wien in den Fahren 1952 bis 1954, p. 51.
} 
was allowed to pick out the richest nuggets of the IKG library collection. This permanent loan, consisting principally of literature from rabbinical and Judaic studies, amounted to an estimated seventy-five to eighty percent of the reconstituted IKG library. ${ }^{99}$ The IKG archives - containing valuable and comprehensive documentary records of the prewar religious community, which had been stored separately from the library - survived the Holocaust nearly intact and were put on permanent loan in Jerusalem at the Central Archives for the History of the Jewish People. ${ }^{100}$

In 1970 the IKG made a gift of 346 older literary works to the city of Beth Shemesh in Israel for the use of its German-speaking citizens. ${ }^{101}$ Among these may well have been fiction and poetry that the Offenbach depot had returned to Vienna after the war. In reaction to further requests from Bar Ilan and Tel Aviv University, leaders of the Jewish community sent a letter to the Israeli Minister of Religion in 1971 containing the statement: "What still remains here is only a small fraction [of what once was], and we really can't dispossess ourselves of it, since we want to keep hold of something with at least symbolic intellectual value."102

Around 1984 the decision was definitively made that any attempt to recreate the great and lost Jewish community library of Vienna was neither feasible nor desirable. ${ }^{103}$ What remained as a successor institution was different; it became an adjunct to a museum whose main task was to look backwards. Parallel to those People of the Book who had assembled the communal collection for decades with exquisite devotion and parallel to those who continued to read from its pages when Austria had entered a time of unrighteousness, the historic library passed into the ages - scattered, abused and annihilated, but leaving a remnant of remembrance.

\footnotetext{
${ }^{99}$ Adunka, Die vierte Gemeinde, p. 305; Grosz, p. 168; author's interview with Ronald Grosz on 1 October 1999.

${ }^{100}$ Adunka, Die vierte Gemeinde, p. 305 . There are at least two orally transmitted, contradictory and somewhat imprecise explanations of how the archives survived the war.

${ }^{101}$ ibid.

${ }^{102}$ IKG Archives, Binder 175, XXX, c/d, Letter of 12 May 1971 to Bar Ilan, as quoted in Adunka, Die vierte Gemeinde, p. 306.

${ }^{103}$ Ronald Grosz, 'Building a New Library Around an Old Collection: The Example of the Library of the Jewish Museum of Vienna', a presentation at the annual conference of the Association of Jewish Libraries in Boca Raton, Florida, 22 June 1999; transcript in possession of the author.
} 